medRxiv preprint doi: https://doi.org/10.1101/2021.11.24.21266804; this version posted November 24,2021 . The copyright holder for this preprint (which was not certified by peer review) is the author/funder, who has granted medRxiv a license to display the preprint in

\title{
1 The effect of secretor status and the vaginal microbiome on birth outcome
}

3 Kundu $\mathrm{S}^{1}$, Lee $Y S^{1}$, Sykes $\mathrm{L}^{1,2}$, Chan $\mathrm{D}^{2}$, Lewis $\mathrm{H}^{2}$, Brown $R \mathrm{G}^{2}$, Kindinger $\mathrm{L}^{2,3}$, Dell $4 \quad \mathrm{~A}^{1,4}$, Feizi $\mathrm{T}^{1,5}$, Haslam $\mathrm{S}^{1,4}$, Liu $\mathrm{Y}^{1,5}$, Marchesi $\mathrm{JR}^{1,6}$, Maclntyre $\mathrm{DA}^{1,2^{\star}}$ and Bennett $5 \quad \mathrm{PR}^{1,2}$.

$7 \quad{ }^{1}$ March of Dimes European Prematurity Research Centre, Imperial College London

8 2Institute for Reproductive and Developmental Biology, Imperial College London,

9 Hammersmith Hospital Campus, London W12 0NN, United Kingdom

10 3Institute for Women's Health, University College London, London, UK

$11 \quad{ }^{4}$ Department of Life Sciences, Imperial College London, London, UK

$12{ }^{5}$ Glycosciences Laboratory, Department of Metabolism Digestion and Reproduction,

13 Imperial College London, London, UK

$14{ }^{6}$ Division of Digestive Medicine, Department of Metabolism, Digestion and

15 Reproduction, Faculty of Medicine, Imperial College London, UK.

${ }^{*}$ Correspondence to Dr D.A. Maclntyre (d.macintyre@imperial.ac.uk)

\section{Summary}

19 Mutations in the FUT2 gene that result in a lack of expression of histo-blood group 20 antigens on secreted glycoproteins may shape the vaginal microbiota with 21 consequences for birth outcome. To test this, we analysed the relationship between secretor status, vaginal microbiota and gestational length in an ethnically diverse cohort of 313 pregnant women, including 91 who delivered prematurely. Lactobacillus species were found to co-occur less often with other microbial taxa in non-secretors.

Moreover, non-secretors with Lactobacillus spp. depleted vaginal microbiota in early NOTE: This preprint reports new research that has not been certified by peer review and should not be used to guide clinical practice. 
medRxiv preprint doi: https://doi.org/10.1101/2021.11.24.21266804; this version posted November 24, 2021. The copyright holder for this preprint (which was not certified by peer review) is the author/funder, who has granted medRxiv a license to display the preprint in It is made available under a CC-BY-ND 4.0 International license .

26 pregnancy had significantly shorter gestational length than Lactobacillus spp.

27 dominated non-secretors (mean of $245.5(\mathrm{SD}=44.5)$ versus $265.9(23.6)$ ); $\mathrm{p}=0.045)$,

28 but not compared to Lactobacillus spp. dominated (261.8 (27.5)) and depleted (264.3

29 days (21.2)) secretors. In identifying a relationship between blood-group antigen

30 expression and vaginal microbiota-host interactions, our results point towards

31 stratification by secretor status as an important factor for considering preterm birth risk 32 and prevention.

33

34 Keywords

35 Preterm birth, Secretor, blood-type antigens, vaginal microbiome, Lactobacillus 36 dominance 
medRxiv preprint doi: https://doi.org/10.1101/2021.11.24.21266804; this version posted November 24,2021 . The copyright holder for this preprint (which was not certified by peer review) is the author/funder, who has granted medRxiv a license to display the preprint in

\section{Introduction}

Histo-blood group antigens (HBGA), ABH and Lewis, are carbohydrate sequences

found on the surface of a range of cell types and in secretions such as cervico-vaginal fluid. These antigens can serve as attachment sites and energy sources for microbial organisms $^{1-3}$. The FUT2 gene encodes the $\alpha(1,2)$-fucosyltransferase enzyme, which adds a fucose residue to the terminal galactose on a type 1 glycan precursor forming the $\mathrm{H}$ antigen. Four mutations in the FUT2 gene have been identified (alleles $s e^{302}$, $s e^{385}, s e^{428}$ and $s e^{571}$ ) that result in non-secretion of these antigens from mucosal surfaces, in homozygotes, and up to $20 \%$ of human populations express this nonsecretor phenotype ${ }^{4-7}$. Non-secretors will present as either Le(a+b-) or Le(a-b-), depending upon the presence of mutations in their FUT3 gene. Secretor status has been associated with increased and decreased susceptibility to a range of bacterial and viral pathogens as well as gut microbiota composition ${ }^{8-14}$.

The vaginal microbiome plays an important role in influencing pregnancy outcome.

51 Dominance of the vaginal niche by Lactobacillus species has been widely reported to associate with healthy, term pregnancy ${ }^{15,16}$. In contrast, high diversity microbial communities depleted of Lactobacillus species and enriched with pathobionts and/or bacterial vaginosis (BV)-associated bacteria, increase the risk of adverse pregnancy outcomes including miscarriage and preterm birth ${ }^{17-19}$. Preterm birth represents a significant global health burden - it is the leading cause of death in children under age five and associates with serious short and long-term morbidities in survivors ${ }^{20-22}$. Significant risk factors for spontaneous preterm birth in our populations include history of late miscarriage or preterm birth, and previous cervical excisional treatment, an operation to treat cervical pre-cancer ${ }^{23,24}$. Both of these risk factors have been linked with characteristic compositions of the vaginal microbiota ${ }^{15,16,25,26}$. 
medRxiv preprint doi: https://doi.org/10.1101/2021.11.24.21266804; this version posted November 24, 2021. The copyright holder for this preprint (which was not certified by peer review) is the author/funder, who has granted medRxiv a license to display the preprint in It is made available under a CC-BY-ND 4.0 International license .

62 In a recent study of 300 pregnant women (of whom 28 experienced preterm birth),

63 maternal secretor status was reported as an independent risk factor for preterm

64 delivery (Caldwell et al., 2020). Specific human milk oligosaccharides (HMOs) in blood

65 and urine have also been recently associated with vaginal microbiota in a small cohort

$66(n=60)$ of women presenting with threatened preterm labour (Pausen et al., 2020). We

67 postulated that the composition of the vaginal microbiota in pregnancy might be

68 influenced by maternal secretor status, and that this may influence pregnancy

69 duration. To characterise the effect of secretor status on the vaginal microbiome and

70 gestational length, we sequenced the second exon of the FUT2 gene to infer secretor

71 status and undertook metataxonomic analysis of vaginal samples collected

72 longitudinally from a cohort of 313 pregnant women, of which 91 delivered

73 prematurely. 
medRxiv preprint doi: https://doi.org/10.1101/2021.11.24.21266804; this version posted November 24,2021 . The copyright holder for this preprint (which was not certified by peer review) is the author/funder, who has granted medRxiv a license to display the preprint in

\section{Results/Discussion}

Distribution of non-secretors in our cohort

A total of 313 women were included in our study (Supplementary Table S1), of which 91 experienced spontaneous preterm birth before 37 weeks (259 days) of gestation. The ethnic distribution of the cohort was similar to the expected background prevalence within the clinical population. In total, 87 women were identified as nonsecretors and 141 as heterozygous at these loci. Although nine women were heterozygous at multiple non-secretor loci, we did not identify any who were multiply homozygous. All four known non-secretor mutations were identified in our cohort. The $s e^{428}$ nonsense mutation accounted for $89.7 \%$ of the heterozygotes and $94 \%$ of the non-secretor homozygotes and was present across all ethnicities except East Asian patients. The remaining mutations had more restricted distributions: five women of East Asian ethnicity were homozygous for the $\mathrm{se}^{385}$ non-secretor allele (and a further five who were heterozygous) and only one $s^{302}$ homozygote was identified in a woman of Central-South Asian descent (ten other women, of similar ethnicity, were heterozygous). We did not identify any homozygotes of $s e^{571}$. These patterns are consistent with previously documented distributions of non-secretor genetic diversity 5-7. Overall, $28 \%$ of the cohort were identified as non-secretor with the highest proportion in Afro-Caribbean women, 34.6\%, compared with $26.8 \%$ and $19.2 \%$ in

94 European and Central-South Asian ethnicities respectively. For all subsequent analyses secretor homozygotes were combined with heterozygotes into a single group since they are phenotypically similar ${ }^{27}$.

Lactobacilli are more refractory to co-colonisation in non-secretors 
medRxiv preprint doi: https://doi.org/10.1101/2021.11.24.21266804; this version posted November 24,2021 . The copyright holder for this preprint (which was not certified by peer review) is the author/funder, who has granted medRxiv a license to display the preprint in

allows comparisons across datasets ${ }^{28,29}$. The most prevalent CST observed in our cohort was CST 1 (majority L. crispatus) in 39.7, 45.9 and $41.1 \%$ of the patients at early, mid and late gestation respectively, followed by CST 3 (majority L. iners) in 30.0, 23.1 and $27.7 \%$, CST 4 (diverse) in $14.3,12.8$ and $16.6 \%$, CST 2 (majority L. gasseri) in $10.1,10.7$ and $7.5 \%$ and CST 5 (majority L. jensenii) in 5.9, 7.5 and $7.1 \%$. In samples taken during early pregnancy, prior to any interventions, we observed a similar prevalence of major bacterial genera across secretor and non-secretor women,

107 including those classically associated with BV (a clinical syndrome of vaginal 108 discharge and odour characterised by polymicrobial overgrowth), e.g., Gardnerella,

109 Atopobium, Anaerococcus and Sneathia, (Figure 1A). As expected, most women had 110 a high relative abundance of Lactobacillus, though in the secretors there was evidence 111 of a greater spread (Figure 1B). At species level, an enrichment for CST 3 in non112 secretors and CST 4 in secretors was observed but these differences were not 113 statistically significant (Fisher's Exact test $p=0.163$, Figure $1 C$ ).

114 We observed no difference in bacterial diversity (Shannon Index) between non115 secretors and secretors in early pregnancy ( $p$-value=0.409) nor any differential 116 classification in principal components analysis (PCA) (p-value=0.303). Differential 117 abundance analyses (DAA) suggested no significant differences of relative abundance 118 in species on the basis of secretor phenotype (Supplementary Figure S1) however, 119 the low prevalence of Lactobacillus depleted patients (26.8\% of all early pregnancy 120 samples) in our cohort may have limited our power to detect such associations. Low 121 prevalence of Lactobacillus depleted vaginal communities is likely attributable to 122 increased relative abundance of Lactobacillus species in the vaginal microbiome 123 during pregnancy and consistent with our clinical population: mostly women with 124 European ancestry who, compared to other ethnicities, have higher prevalence of 
medRxiv preprint doi: https://doi.org/10.1101/2021.11.24.21266804; this version posted November 24,2021 . The copyright holder for this preprint (which was not certified by peer review) is the author/funder, who has granted medRxiv a license to display the preprint in It is made available under a CC-BY-ND 4.0 International license.

125 Lactobacillus-dominated vaginal microbiomes ${ }^{28,30}$. A recent study of 60 women

126 presenting with suspected preterm labour reported positive associations between

127 specific urinary and blood human milk oligosaccharides, and some vaginal taxa and

128 clinical outcomes including preterm birth ${ }^{31}$. However, it is difficult to compare these

129 findings to our own given that over half of their patient cohort received tocolysis to

130 inhibit uterine contractions and prevent preterm birth (only a small number of women

131 in their study cohort experienced preterm birth, $n=11$ ).

132 To investigate whether vaginal microbial community structure might differ between

133 secretors and non-secretors, we compared co-occurrence networks inferred from

134 correlation matrices based on the $16 \mathrm{~S}$ relative abundance data (Figure 2) as 135 previously described ${ }^{32}$. For this analysis, non-Lactobacillus taxa were classified as 136 'pathobionts', 'BV-associated' or 'other' using definitions from Wijgert et al ${ }^{33}$. In both

137 the secretor and non-secretor microbial networks, nodes representing BV-associated

138 bacteria tended to be connected via positive edges, reflecting positive correlations

139 among these microbes (Figure 2A). Analysis of node importance, using Expected 140 Influence (EI) ${ }^{34}$ as a metric, confirmed this pattern, i.e., that in both networks, nodes 141 with the most positive El scores were BV-associated bacteria and pathobionts, such 142 as Prevotella timonensis and Finegoldia magna (Supplementary Figure S2). These 143 patterns mirror previous studies showing that these microbes establish interactions

144 based on mutualistic relationships ${ }^{35,36}$. In non-secretors $L$. crispatus, $L$. jensenii and 145 L. iners were the most negatively scored nodes for $\mathrm{El}$, but in secretors, a greater 146 proportion of positive edges from these lactobacilli to other BV-associated microbes 147 was observed (Figure 2B and Supplementary Figure S2). These results suggest that 148 Lactobacillus species, particularly L. crispatus, are more refractory to co-colonisation 149 in non-secretors where they may offer a greater "protective" effect via competitive 
medRxiv preprint doi: https://doi.org/10.1101/2021.11.24.21266804; this version posted November 24,2021 . The copyright holder for this preprint (which was not certified by peer review) is the author/funder, who has granted medRxiv a license to display the preprint in

exclusion. These findings are consistent with comparative genomics studies that have

151 highlighted bacterial cell surface glycoconjugates and carbohydrate-binding proteins as potentially important mediators of vaginal microbiota-host ${ }^{37}$.

153 Non-secretors with Lactobacillus depleted microbiomes are associated with shorter

154 gestational length

155 On the basis of the distribution of Lactobacillus abundance (Figure 1C) and previous studies ${ }^{38,39}$ we classified the vaginal microbiome into Lactobacillus dominated (>90\% Lactobacillus spp.) and depleted states (<90\%). Non-secretors with a Lactobacillus depleted microbiome in early pregnancy had a shorter mean gestational length 245.5 days $(S D=44.5)$ compared to Lactobacillus dominated non-secretors, 265.9 days

160 (SD=23.6) and to both Lactobacillus depleted and dominated secretors, 264.3

$161(S D=21.2)$ and $261.8(S D=27.5)$ days, respectively (Figure 3A). However, the association between Lactobacillus status in non-secretors on gestational outcome was diminished by mid pregnancy. To confirm these observations, for each sampling

164 timepoint we modelled gestational length on secretor status and the vaginal microbiome (Lactobacillus status) together with BMI, age, cervical cerclage status and previous pregnancy history, i.e. cervical excisional treatment (LLETZ) and a combined previous preterm birth (PTB) and/or mid-trimester loss (MTL) covariate using generalised linear mixed effects modelling (GLMM) with ethnicity as a random effect

169 (Table 1). As expected, previous pregnancy histories were significant explanatory 170 variables of gestational length (Supplementary Table S3). Comparison of the GLMMs 171 with generalised linear models (GLM) showed similar model fits (for example, AIC 1722495.225 and 2497.225 for the GLM and GLMM, respectively, for the early pregnancy 173 modelling) indicating that ethnicity was not a significant factor in the model. However, 174 the early pregnancy GLMM showed that the secretor status and Lactobacillus status 
medRxiv preprint doi: https://doi.org/10.1101/2021.11.24.21266804; this version posted November 24,2021 . The copyright holder for this preprint (which was not certified by peer review) is the author/funder, who has granted medRxiv a license to display the preprint in

175

176

177

178

179

180

181

182

183

184

185

186

187

188

189

190

191

192

193

194

195

196

197

198

199

interaction term is a significant explanatory variable of gestational length $(p=0.02)$.

This significance disappeared by mid-pregnancy supporting our earlier observation that non-secretors with a Lactobacillus depleted vaginal microbiome in early pregnancy, but not mid-pregnancy, are associated with shorter gestational lengths. Post hoc testing using the estimated marginal means confirmed this significant comparison ( $p$-value $=0.045)$, but also indicated that a difference in gestational length may exist between Lactobacillus depleted non-secretors (mean gestation of 245.5 days) and Lactobacillus depleted secretors (mean gestation of 264.3 days) (pvalue=0.068). No significant difference between Lactobacillus dominated and depleted secretors was found ( $p$-value $=0.283)$.

When vaginal microbiomes were classified into CSTs, non-secretors with CST 2, 3 or 4 in early pregnancy had shorter gestations, mean $( \pm S D)$ of $249.3(34.1), 260.5(26.9)$ and 232.2 (61.4) days, respectively, compared to CST 1 (269.4 days (19.7)) (Figure 3B). A similar pattern was observed with CST 5 (mean of 278 days), however sample size was limited to only $n=4$. By contrast, gestational length in secretors was broadly similar across all CSTs: mean gestational length ( \pm SD) of $264.0(28.4), 264.7(20.5)$, 258.0 (29.4), 264.1 (18.2) and 262.6 (26.0) respectively in CST 1, 2, 3, 4 and 5. In line with these findings, modelling gestational length with early pregnancy CST (Table 1) showed that the interaction term between CST and secretor status was statistically significant ( $p$-value=0.017). By mid-pregnancy, this interaction term was not statistically significant (Supplementary Table S4). The estimated marginal means identified the gestational length differences in the non-secretors between CST 1 versus CST 2, and CST 1 versus CST 4 to be statistically significant (respectively, pvalue $=0.037$ and 0.033 ). Trend differences were also observed in the non-secretors between CST 2 and 5 ( $p$-value=0.059), and CST 4 and $5(p$-value=0.051). These post 
medRxiv preprint doi: https://doi.org/10.1101/2021.11.24.21266804; this version posted November 24,2021 . The copyright holder for this preprint (which was not certified by peer review) is the author/funder, who has granted medRxiv a license to display the preprint in It is made available under a CC-BY-ND 4.0 International license.

hoc tests also identified a difference in gestational length between secretors and nonsecretors with CST 1 vaginal microbiomes in early pregnancy ( $p$-value $=0.017)$.

Our findings are consistent with a previous study by Lurie et al ${ }^{40}$ who identified a significantly elevated proportion of non-secretors in a cohort of 28 patients who suffered preterm premature rupture of the membranes (PPROM) compared with term patients. PPROM precedes approximately $30 \%$ of all preterm birth cases and has been associated with ascending infection in the vagina ${ }^{18,41}$.

Caldwell et al ${ }^{42}$ also reported that maternal secretor status is a potential biomarker for prematurity. Our data supports these findings but demonstrates that this relationship is likely shaped by the vaginal microbiota in early pregnancy. Dominance of the vaginal niche by Lactobacillus spp. is considered to be a hallmark of vaginal health due to the role that these species play in preventing colonisation of other microbes through the promotion of a hostile, acidic mucosal environment enriched by bacteriocins and other antimicrobial compounds ${ }^{43,44}$. Our results support previous findings in highlighting this protective role extending into pregnancy, but demonstrate that this is nuanced by host secretor status. Studies identifying an association between vaginal Lactobacillus spp. depletion and increased risk of preterm birth ${ }^{19,28,45,46}$ also emphasise that high diversity vaginal bacterial communities do not always result in preterm birth (as is the case of the secretors). An enhanced inflammatory response, previously observed in non-secretors ${ }^{47}$, may provide a mechanism linking gestational length to secretor status and vaginal microbiota but this requires further investigation. It is possible that $A B O$ blood groups influence the relationship between secretor status and the microbiota by affecting terminal glycan structures. To address this, we incorporated $\mathrm{ABO}$ status into our models and observed that there may be evidence of 
medRxiv preprint doi: https://doi.org/10.1101/2021.11.24.21266804; this version posted November 24,2021 . The copyright holder for this preprint (which was not certified by peer review) is the author/funder, who has granted medRxiv a license to display the preprint in

shorter gestational length in blood group B women compared to blood group A, though this was only observed at mid-pregnancy (Supplementary Table S5).

226 Early developmental stages in pregnancy have lasting effects on pregnancy gestation and outcome. Our results indicate that the relationship between Lactobacillus depletion and reduced gestational length in non-secretors is altered as pregnancy progresses and points towards the microbiota-host interactions in early pregnancy being particularly key in shaping preterm birth risk. This result is consistent with

231 findings from Stout and colleagues who showed that, in a predominantly AfricanAmerican cohort, early gestation is an ecologically important time for events that predict subsequent term and preterm birth ${ }^{48}$. Similarly, Tabatabaei and coworkers ${ }^{49}$ identified an association between Lactobacillus depleted vaginal microbiota in early pregnancy and increased risk of early preterm birth in a cohort of Canadian women of predominantly white European origin. Lactobacillus depletion is also a risk factor for miscarriage, which collectively suggests a potential effect of the vaginal microbiota upon decidual function and placentation ${ }^{17,50,51}$.

\section{Concluding remarks}

240 In this study we identify a subset of women, non-secretors with Lactobacillus depleted

241 vaginal microbiomes, who are predisposed to shorter gestational length. This

242 stratification could allow a more targeted intervention of "at-risk" pregnancies, although

243 these results should be verified with larger numbers of Lactobacillus depleted 244 samples. We find evidence of a more "protective" role of Lactobacillus species, especially L. crispatus, in non-secretors. Whilst further studies are required to

246 elucidate the mechanisms underlying these interactions in secretors and non247 secretors, the data supports the evolving concept that L. crispatus offers optimal 
medRxiv preprint doi: https://doi.org/10.1101/2021.11.24.21266804; this version posted November $24,2021$. The copyright holder for this preprint (which was not certified by peer review) is the author/funder, who has granted medRxiv a license to display the preprint in It is made available under a CC-BY-ND 4.0 International license.

248 protection against preterm birth and is a candidate for development of live

249 biotherapeutic therapies during pregnancy. 
medRxiv preprint doi: https://doi.org/10.1101/2021.11.24.21266804; this version posted November 24,2021 . The copyright holder for this preprint (which was not certified by peer review) is the author/funder, who has granted medRxiv a license to display the preprint in

\section{Resource Availability}

252 Further information and requests for supporting data, resources, and reagents should

253 be directed to the Lead Contact: David Maclntyre (d.macintyre@imperial.ac.uk).

254 Materials Availability

255 Reagents from this study are available upon request.

256 Data and Code Availability

257 All sequencing data used in this study has been made available in ENA database

258 (Accession numbers ERR4864561-ERR4865307). Python and R scripts used in

259 support of the analyses are available at: https://github.com/samitkundu/FUT2.

260 Acknowledgements

261 The study was funded by the March of Dimes. The funder had no role in the study

262 design, data collection and analysis, and preparation of the manuscript.

\section{Author Contributions}

264 Conceptualization, D.A.M., P.R.B. and S.K.; Methodology, D.A.M., P.R.B. and S.K.;

265 Investigation, D.C., R.G.B., L.K., S.K. and Y.S.L.; Resources, D.C., H.L., L.K., L.S.

266 and R.G.B.; Formal Analysis, S.K.; Writing - Original draft, D.A.M., P.R.B. and S.K.;

267 Writing - Review and Editing, A.D., D.A.M., H.L., J.M., L.S., P.R.B., S.H., S.K., T.F.,

268 Y.L., Y.S.L.; Funding Acquisition, D.A.M. and P.R.B.; Supervision, D.A.M. and P.R.B.

269 Competing Interests

270 The authors declare no competing interests. 
medRxiv preprint doi: https://doi.org/10.1101/2021.11.24.21266804; this version posted November 24,2021 . The copyright holder for this preprint (which was not certified by peer review) is the author/funder, who has granted medRxiv a license to display the preprint in

\section{Methods}

273 Ethics Statement

274 The study was conducted with approval of the NHS National Research Ethics Service

275 (NRES) Committees London - City and East (REC 12/LO/2003) and London-

276 Stanmore (REC 14/LO/0328), and by the North of Scotland Research Ethics Service

277 (REC 14/NS/1078). Written informed consent was obtained from all patients prior to

278 sampling and experiments were performed in accordance with the approved

279 institutional guidelines.

280 Patient sampling

281 Recruitment and sampling were performed at Imperial College Healthcare NHS Trust

282 Hospitals (Queen Charlotte's and Chelsea and St Mary's Hospitals), London, UK, at

283 Chelsea \& Westminster Hospital (NHS Trust, London, UK), University College London

284 Hospital (NHS Foundation Trust, London, UK) and the Royal Infirmary of Edinburgh,

285 Scotland, UK. Eligibility criteria included singleton pregnancies, with and without risk

286 factors for preterm birth. Exclusion criteria included women under 18 years of age,

287 those who had sexual intercourse within $72 \mathrm{~h}$ of sampling, vaginal bleeding in the

288 preceding week, antibiotic use in the preceding 2 weeks, multiple pregnancies, HIV or

289 Hepatitis C positive status. Detailed maternal clinical metadata and birth outcome data

290 was collected for all participants. Cervicovaginal fluid swab samples were collected

291 from the posterior fornix using BBL CultureSwab MaxV Liquid Amies swabs (Becton,

292 Dickinson and Company, Oxford, UK) at up to three timepoints throughout pregnancy;

early (63 to 130 days), mid (118-180 days) and late (163-252 days). Swabs were

294 immediately placed in Amies transport media and stored at $-80^{\circ} \mathrm{C}$.

295 Determination of secretor status 
medRxiv preprint doi: https://doi.org/10.1101/2021.11.24.21266804; this version posted November 24,2021 . The copyright holder for this preprint (which was not certified by peer review) is the author/funder, who has granted medRxiv a license to display the preprint in

296 Extraction of DNA from vaginal swabs was performed as previously described ${ }^{30}$.

297 Individuals were genotyped by sequencing the coding part of exon 2 of the FUT2 gene.

298 The exon was amplified using primers 5'-CCATATCCCAGCTAACGTGTCC-3' and 5'-

299 GGGAGGCAGAGAAGGAGAAAAGG-3 ${ }^{52}$ and the amplicons sequenced with the

300 PacBio Sequel system. Primer sequences were removed from the CCS reads using

301 Dada2 ${ }^{53}$ and the trimmed sequences mapped to a human reference FUT2 sequence

302 (derived from HG38) using Minimap ${ }^{54}$. To limit the effect of any reference bias, we

303 generated consensus sequences using the "ALT" allele from the mapping and reads

304 were remapped to this sequence. Finally, variants were called using Freebayes ${ }^{55}$ and

305 phased using WhatsHap ${ }^{56}$.

306 Individuals that were homozygous for any one of the four known non-secretor mutations (se302 (P101L, rs200157007), se385 (I129F, rs1047781), se428 (W413X, rs601338) and se571(R191X, rs18000028)) were inferred to be phenotypically nonsecretor 4-6,57. Heterozygotes and wildtype homozygotes were classified as secretors $310 \quad 27$.

311 Sequencing of 165 rRNA gene amplicons and assembly

312 The V1-V2 hyper variable regions of bacterial 16S rRNA genes were amplified with

313 using the forward primer set (28f-YM) consisting of a mixture of the following primers

314 mixed at a 4:1:1:1 ratio; 28F-Borrellia GAGTTTGATCCTGGCTTAG; 28F-Chlorflex

315 GAATTTGATCTTGGTTCAG; 28F-Bifido GGGTTCGATTCTGGCTCAG; 28F

316 GAGTTTGATCNTGGCTCAG. The reverse primer consisted of; 388R

317 TGCTGCCTCCCGTAGGAGT ${ }^{58}$. Primer sequences were trimmed using Cutadapt ${ }^{59}$, 318 performed QC using FastQC ${ }^{60}$ and calculated ASV counts per sample using the

319 Qiime2 pipeline ${ }^{61}$. We used DADA2 ${ }^{53}$ for denoising and taxonomically classified 320 sequences to species level using the STIRRUPS reference database ${ }^{62}$. 
medRxiv preprint doi: https://doi.org/10.1101/2021.11.24.21266804; this version posted November 24,2021 . The copyright holder for this preprint (which was not certified by peer review) is the author/funder, who has granted medRxiv a license to display the preprint in

Data analyses

322 Generalised linear mixed effects gamma regression models for each timepoint in

323 pregnancy were used to regress gestational length (in days) on secretor status and

324 the vaginal microbiome (Lactobacillus status or CST) as well as age, BMI, previous

325 PTB/MTL, cervical stitch and Previous cervical excisional treatment in glmmTMB ${ }^{63}$.

326 We used ethnicity as a random effect: as the sample size for the East Asian and Middle

327 East North African and Mixed/Other groups was small (less than 10) these were

328 combined into a single group (Mixed/Other). We applied a reflection transformation to

329 the gestational length prior to fitting the gamma GLMM as this variable was negatively

330 skewed. Model diagnostics were examined with scaled residuals simulated from the

331 fitted models using DHARMa ${ }^{64}$. We used the emmeans package to calculate the

332 estimated marginal means from the models to look for statistically significant

333 comparisons between groups ${ }^{65}$ : this post hoc method automatically adjusts for

334 multiple comparisons.

335 We retained taxa that occurred at greater than $0.5 \%$ abundance in two or more

336 samples. Differential abundance analyses were performed using ALDEx2 to compare

337 taxon abundances in the vaginal microbiome in early pregnancy between secretors

338 and non-secretors 66,67 . This method uses a compositionally robust approach to

339 perform DAA: microbiome count data are considered compositional and thus have to

340 be transformed to permit analysis by multivariate statistics ${ }^{68}$. Count data were

341 transformed with the centred log-ratio (CLR) and we ran 1000 Monte-Carlo instances

342 to estimate effect sizes and perform a Welch's t test to compare our two conditions.

343 We also analysed the compositional differences between phenotypes using PCAs:

344 zeros in the count data were imputed using a Bayesian multiplicative approach in the

345 zCompositions package ${ }^{69}$ followed by CLR-transformation. To test whether the 
medRxiv preprint doi: https://doi.org/10.1101/2021.11.24.21266804; this version posted November 24,2021 . The copyright holder for this preprint (which was not certified by peer review) is the author/funder, who has granted medRxiv a license to display the preprint in It is made available under a CC-BY-ND 4.0 International license.

346 centroids of the two secretor groups differ we performed a PERMANOVA on the CLR-

347 transformed distance matrix (after checking for homogeneity of dispersion) using the

348 Vegan package ${ }^{70}$

349 Finally, we used BAnOCC to infer co-occurrence networks for the microbial taxa

350 observed in secretors and non-secretors in early pregnancy ${ }^{71}$. This program uses a

351 Bayesian framework to analyse compositional covariance. We ran the MCMC for

35210000 generations and four chains to reach convergence. We used a 95\% credible

353 interval to identify significant correlations. Qgraph was used to draw the networks

354 based on these Banocc-derived adjacency matrices and to calculate the Expected

355 Influence network statistic, which is a measure of degree centrality for signed networks $356 \quad 34,72$. 
medRxiv preprint doi: https://doi.org/10.1101/2021.11.24.21266804; this version posted November 24,2021 . The copyright holder for this preprint (which was not certified by peer review) is the author/funder, who has granted medRxiv a license to display the preprint in

\section{References}

359 1. Audfray A, Varrot A, Imberty A. Bacteria love our sugars: Interaction between soluble lectins and human fucosylated glycans, structures, thermodynamics and design of competing glycocompounds. Comptes Rendus Chim. 2013 May;16(5):482-90.

2. Marcobal A, Southwick AM, Earle KA, Sonnenburg JL. A refined palate: Bacterial consumption of host glycans in the gut. Glycobiology. 2013 Sep $1 ; 23(9): 1038-46$.

3. McGuckin MA, Lindén SK, Sutton P, Florin TH. Mucin dynamics and enteric pathogens. Nat Rev Microbiol. 2011;9(4):265-78.

4. Kelly RJ, Rouquier S, Giorgi D, Lennon GG, Lowe KB. Sequence and expression of a candidate for the Human Secretor blood group alpha(1,2)Fucosyltransferase gene (FUT2). J Biol Chem. 1995;270(9):4640-9.

5. Soejima M, Pang H, Koda Y. Genetic variation of FUT2 in a Ghanaian population: identification of four novel mutations and inference of balancing selection. Ann Hematol. 2007 Jan 26;86(3):199-204.

6. Birney E, Stamatoyannopoulos JA, Dutta A, Guigó R, Gingeras TR, Margulies $\mathrm{EH}$, et al. Identification and analysis of functional elements in $1 \%$ of the human genome by the ENCODE pilot project. Nature. 2007;447(7146):799-816.

7. Ferrer-Admetlla A, Sikora M, Laayouni H, Esteve A, Roubinet F, Blancher A, et al. A natural history of FUT2 polymorphism in humans. Mol Biol Evol. 2009;26(9):1993-2003.

8. Carlsson B, Kindberg E, Buesa J, Rydell GE, Lidón MF, Montava R, et al. The 
medRxiv preprint doi: https://doi.org/10.1101/2021.11.24.21266804; this version posted November 24,2021 . The copyright holder for this preprint (which was not certified by peer review) is the author/funder, who has granted medRxiv a license to display the preprint in

PLoS One. 2009 May 18;4(5):e5593.

384 9. Blackwell CC, Jónsdóttir K, Hanson M, Todd WTA, Chaudhuri AKR, Mathew

$B$, et al. Non-secretion of $A B O$ antigens predisposing to infection by Neisseria meningitidis and Streptococcus pneumoniae. Lancet. 1986 Aug;328(8501):284-5.

10. Blackwell CC, Jonsdottir K, Hanson MF, Weir DM. Non-secretion of ABO blood group antigens predisposing to infection by Haemophilus influenzae. Lancet. 1986 Sep;328(8508):687.

11. Wacklin P, Tuimala J, Nikkilä J, Sebastian Tims, Mäkivuokko H, Alakulppi N, et al. Faecal Microbiota Composition in Adults Is Associated with the FUT2 Gene Determining the Secretor Status. Quince C, editor. PLoS One. 2014 Apr 14;9(4):e94863.

12. Rausch P, Rehman A, Kunzel S, Hasler R, Ott SJ, Schreiber S, et al. Colonic mucosa-associated microbiota is influenced by an interaction of Crohn disease and FUT2 (Secretor) genotype. Proc Natl Acad Sci. 2011 Nov 22;108(47):19030-5.

13. Wacklin P, Mäkivuokko H, Alakulppi N, Nikkilä J, Tenkanen H, Räbinä J, et al. Secretor genotype (FUT2 gene) is strongly associated with the composition of bifidobacteria in the human intestine. PLoS One. 2011;6(5).

14. Lewis ZT, Totten SM, Smilowitz JT, Popovic M, Parker E, Lemay DG, et al. Maternal fucosyltransferase 2 status affects the gut bifidobacterial communities of breastfed infants. Microbiome. 2015 Dec 10;3(1):13. microbiome and preterm birth. Semin Immunopathol. 2020 Aug 14;42(4):48799. 
medRxiv preprint doi: https://doi.org/10.1101/2021.11.24.21266804; this version posted November 24,2021 . The copyright holder for this preprint (which was not certified by peer review) is the author/funder, who has granted medRxiv a license to display the preprint in It is made available under a CC-BY-ND 4.0 International license.

408

16. Bennett PR, Brown RG, MacIntyre DA. Vaginal Microbiome in Preterm Rupture of Membranes. Obstet Gynecol Clin North Am. 2020 Dec;47(4):50321.

17. Al-Memar M, Bobdiwala S, Fourie H, Mannino R, Lee Y, Smith A, et al. The association between vaginal bacterial composition and miscarriage: a nested case-control study. BJOG An Int J Obstet Gynaecol. 2020 Jan 31;127(2):26474.

18. Brown RG, Marchesi JR, Lee YS, Smith A, Lehne B, Kindinger LM, et al. Vaginal dysbiosis increases risk of preterm fetal membrane rupture, neonatal sepsis and is exacerbated by erythromycin. BMC Med. 2018;16(1):1-15.

19. Callahan BJ, DiGiulio DB, Goltsman DSA, Sun CL, Costello EK, Jeganathan $\mathrm{P}$, et al. Replication and refinement of a vaginal microbial signature of preterm birth in two racially distinct cohorts of US women. Proc Natl Acad Sci. 2017;114(37):9966-71.

20. Pike KC, Lucas JSA. Respiratory consequences of late preterm birth. Paediatr Respir Rev. 2015;16(3):182-8.

21. Lax ID, Duerden EG, Lin SY, Mallar Chakravarty M, Donner EJ, Lerch JP, et al. Neuroanatomical consequences of very preterm birth in middle childhood. Brain Struct Funct. 2013;218(2):575-85.

22. Chehade H, Simeoni U, Guignard J-P, Boubred F. Preterm Birth: Long Term Cardiovascular and Renal Consequences. Curr Pediatr Rev. 2018;14(4):21926.

23. Goldenberg RL, Culhane JF, lams JD, Romero R. Epidemiology and causes of preterm birth. Lancet. 2008 Jan;371(9606):75-84 .

24. Kyrgiou M, Mitra A, Arbyn M, Stasinou SM, Martin-Hirsch P, Bennett P, et al. 
medRxiv preprint doi: https://doi.org/10.1101/2021.11.24.21266804; this version posted November 24,2021 . The copyright holder for this preprint (which was not certified by peer review) is the author/funder, who has granted medRxiv a license to display the preprint in

Fertility and early pregnancy outcomes after treatment for cervical intraepithelial neoplasia: systematic review and meta-analysis. BMJ. 2014 Oct 28;349(oct28 1):g6192-g6192.

25. Mitra A, Maclntyre DA, Lee YS, Smith A, Marchesi JR, Lehne B, et al. Cervical intraepithelial neoplasia disease progression is associated with increased vaginal microbiome diversity. Sci Rep. 2015 Dec 17;5(1):16865.

26. Mitra A, MacIntyre DA, Ntritsos G, Smith A, Tsilidis KK, Marchesi JR, et al. The vaginal microbiota associates with the regression of untreated cervical intraepithelial neoplasia 2 lesions. Nat Commun. 2020 Dec 24;11(1):1999.

27. Fumagalli M, Cagliani R, Pozzoli U, Riva S, Comi GP, Menozzi G, et al. Widespread balancing selection and pathogen-driven selection at blood group antigen genes. Genome Res. 2009;19(2):199-212.

28. Fettweis JM, Serrano MG, Brooks JP, Edwards DJ, Girerd PH, Parikh HI, et al. The vaginal microbiome and preterm birth. Nat Med. 2019;25(6):1012-21.

29. Brooks JP, Buck GA, Chen G, Diao L, Edwards DJ, Fettweis JM, et al. Changes in vaginal community state types reflect major shifts in the microbiome. Microb Ecol Health Dis. 2017 Jan 1;28(1):1303265.

30. Maclntyre DA, Chandiramani M, Lee YS, Kindinger L, Smith A, Angelopoulos $\mathrm{N}$, et al. The vaginal microbiome during pregnancy and the postpartum period in a European population. Sci Rep. 2015;5(1):8988.

31. Pausan M-R, Kolovetsiou-Kreiner V, Richter GL, Madl T, Giselbrecht E, Obermayer-Pietsch B, et al. Human Milk Oligosaccharides Modulate the Risk for Preterm Birth in a Microbiome-Dependent and -Independent Manner. Jansson JK, editor. mSystems. 2020 Jun 30;5(3).

32. Ma B, Wang Y, Ye S, Liu S, Stirling E, Gilbert JA, et al. Earth microbial co- 
medRxiv preprint doi: https://doi.org/10.1101/2021.11.24.21266804; this version posted November 24,2021 . The copyright holder for this preprint (which was not certified by peer review) is the author/funder, who has granted medRxiv a license to display the preprint in

occurrence network reveals interconnection pattern across microbiomes. Microbiome. 2020 Dec 4;8(1):82.

33. van de Wijgert JHHM, Verwijs MC, Gill AC, Borgdorff H, van der Veer C,

Mayaud P. Pathobionts in the Vaginal Microbiota: Individual Participant Data

Meta-Analysis of Three Sequencing Studies. Front Cell Infect Microbiol. 2020;10(April).

34. Robinaugh DJ, Millner AJ, McNally RJ. Identifying highly influential nodes in the complicated grief network. J Abnorm Psychol. 2016;125(6):747-57.

35. Pybus V, Onderdonk AB. Evidence for a Commensal, Symbiotic Relationship between Gardnerella vaginalis and Prevotella bivia Involving Ammonia: Potential Significance for Bacterial Vaginosis. J Infect Dis. 1997 Feb

36. Machado A, Jefferson K, Cerca N. Interactions between Lactobacillus crispatus and Bacterial Vaginosis (BV)-Associated Bacterial Species in Initial

37. van der Veer C, Hertzberger RY, Bruisten SM, Tytgat HLP, Swanenburg J, de Kat Angelino-Bart A, et al. Comparative genomics of human Lactobacillus crispatus isolates reveals genes for glycosylation and glycogen degradation: implications for in vivo dominance of the vaginal microbiota. Microbiome. $2019 ; 7(1): 49$.

38. Moreno I, Codoñer FM, Vilella F, Valbuena D, Martinez-Blanch JF, JimenezAlmazán J, et al. Evidence that the endometrial microbiota has an effect on implantation success or failure. Am J Obstet Gynecol. 2016 Dec;215(6):684703. 
medRxiv preprint doi: https://doi.org/10.1101/2021.11.24.21266804; this version posted November 24,2021 . The copyright holder for this preprint (which was not certified by peer review) is the author/funder, who has granted medRxiv a license to display the preprint in

Microbiota and Associated Metabolome in Women with Recurrent Implantation

Failure. Fidel PL, Lin X, editors. MBio. 2020 Jun 2;11(3).

40. Lurie S, Ben-Aroya Z, Eldar S, Sadan O. Association of Lewis blood group phenotype with preterm premature rupture of membranes. J Soc Gynecol Investig. 2003;10(5):291-3.

41. Benedetto C, Tibaldi C, Marozio L, Marini S, Masuelli G, Pelissetto S, et al.

42. Caldwell J, Matson A, Mosha M, Hagadorn JI, Moore J, Brownell E. Maternal $\mathrm{H}$-antigen secretor status is an early biomarker for potential preterm delivery. $\mathrm{J}$ Perinatol. 2020 Nov 24;

43. Tamrakar R, Yamada T, Furuta I, Cho K, Morikawa M, Yamada H, et al. bacteria, and bacterial vaginosis scores in pregnant Japanese women. BMC Infect Dis. 2007;7:128.

44. Maclntyre DA, Sykes L, Bennett PR. The human female urogenital microbiome: complexity in normality. Marchesi JR, editor. Emerg Top Life Sci.

45. Elovitz MA, Gajer P, Riis V, Brown AG, Humphrys MS, Holm JB, et al.

Cervicovaginal microbiota and local immune response modulate the risk of spontaneous preterm delivery. Nat Commun. 2019;10(1):1-8.

46. Brown RG, Al-Memar M, Marchesi JR, Lee YS, Smith A, Chan D, et al. 
medRxiv preprint doi: https://doi.org/10.1101/2021.11.24.21266804; this version posted November 24,2021 . The copyright holder for this preprint (which was not certified by peer review) is the author/funder, who has granted medRxiv a license to display the preprint in

47. Lomberg H, Jodal U, Leffler H, Man P De, Svanborg C. Blood Group Non-

Secretors Have an Increased Inflammatory Response to Urinary Tract

Infection. Scand J Infect Dis. 1992 Jan 8;24(1):77-83.

48. Stout MJ, Zhou Y, Wylie KM, Tarr PI, Macones GA, Tuuli MG. Early pregnancy vaginal microbiome trends and preterm birth. Am J Obstet Gynecol. 2017 Sep;217(3):356.e1-356.e18.

49. Tabatabaei N, Eren AM, Barreiro LB, Yotova V, Dumaine A, Allard C, et al. Vaginal microbiome in early pregnancy and subsequent risk of spontaneous preterm birth: a case-control study. BJOG An Int J Obstet Gynaecol. $2019 ; 126(3): 349-58$.

50. Kirkegaard I, Uldbjerg N, Petersen OB, Tørring N, Henriksen TB. PAPP-A, free $\beta$-hCG, and early fetal growth identify two pathways leading to preterm delivery. Prenat Diagn. 2010 Aug 18;30(10):956-63.

51. Lackman F, Capewell V, Richardson B, DaSilva O, Gagnon R. The risks of spontaneous preterm delivery and perinatal mortality in relation to size at birth according to fetal versus neonatal growth standards. Am J Obstet Gynecol. 2001 Apr;184(5):946-53.

52. Silva LM, Carvalho AS, Guillon P, Seixas S, Azevedo M, Almeida R, et al. Infection-associated FUT2 (Fucosyltransferase 2) genetic variation and impact on functionality assessed by in vivo studies. Glycoconj J. 2010 Jan $16 ; 27(1): 61-8$.

53. Callahan BJ, McMurdie PJ, Rosen MJ, Han AW, Johnson AJA, Holmes SP. Methods. 2016 Jul 23;13(7):581-3.

532 54. Li H. Minimap2: pairwise alignment for nucleotide sequences. Birol I, editor. 
medRxiv preprint doi: https://doi.org/10.1101/2021.11.24.21266804; this version posted November 24,2021 . The copyright holder for this preprint (which was not certified by peer review) is the author/funder, who has granted medRxiv a license to display the preprint in

Bioinformatics. 2018 Sep 15;34(18):3094-100.

534 55. Garrison E, Marth G. Haplotype-based variant detection from short-read sequencing. 2012 Jul 17;

56. Patterson M, Marschall T, Pisanti N, van lersel L, Stougie L, Klau GW, et al. WhatsHap : Weighted Haplotype Assembly for Future-Generation Sequencing Reads. J Comput Biol. 2015 Jun;22(6):498-509.

57. Henry S, Mollicone R, Fernandez P, Samuelsson B, Oriol R, Larson G.

Molecular basis for erythrocyte Le $(a+b+)$ and salivary $\mathrm{ABH}$ partial-secretor phenotypes: expression of a FUT2 secretor allele with an A-T mutation at nucleotide 385 correlates with reduced $a(1,2)$ fucosyltransferase activity. Glycoconj J. 1996 Dec;13(6):985-93.

58. Frank JA, Reich CI, Sharma S, Weisbaum JS, Wilson BA, Olsen GJ. Critical Evaluation of Two Primers Commonly Used for Amplification of Bacterial 16S rRNA Genes. Appl Environ Microbiol. 2008 Apr 15;74(8):2461-70.

59. Martin M. Cutadapt removes adapter sequences from high-throughput sequencing reads. EMBnet.journal. 2011 May 2;17(1):10.

60. Andrew S. FastQC: A Quality Control Tool for High Throughput Sequence Data. 2010.

61. Bolyen E, Rideout JR, Dillon MR, Bokulich NA, Abnet CC, Al-Ghalith GA, et al. Reproducible, interactive, scalable and extensible microbiome data science using QIIME 2. Nat Biotechnol. 2019 Aug 24;37(8):852-7.

62. Fettweis JM, Serrano MG, Sheth NU, Mayer CM, Glascock AL, Brooks JP, et al. Species-level classification of the vaginal microbiome. BMC Genomics. 2012 Dec 17;13(S8):S17. 
medRxiv preprint doi: https://doi.org/10.1101/2021.11.24.21266804; this version posted November 24,2021 . The copyright holder for this preprint (which was not certified by peer review) is the author/funder, who has granted medRxiv a license to display the preprint in

al. Modeling zero-inflated count data with glmmTMB. bioRxiv. 2017;132753.

64. Hartig F. DHARMa: residual diagnostics for hierarchical (multi-level/mixed) regression models. 2020.

65. Lenth R, Buerkner P, Herve M, Love J, Riebl H, Singmann H. Estimated Marginal Means, aka Least-Squares Means. 2020.

66. Fernandes AD, Macklaim JM, Linn TG, Reid G, Gloor GB. ANOVA-Like

Parkinson J, editor. PLoS One. 2013 Jul 2;8(7):e67019.

67. Fernandes AD, Reid JN, Macklaim JM, McMurrough TA, Edgell DR, Gloor GB. Unifying the analysis of high-throughput sequencing datasets: characterizing RNA-seq, 16S rRNA gene sequencing and selective growth experiments by compositional data analysis. Microbiome. 2014;2(1):15.

68. Gloor GB, Macklaim JM, Pawlowsky-Glahn V, Egozcue JJ. Microbiome datasets are compositional: And this is not optional. Front Microbiol. $2017 ; 8(\mathrm{NOV}): 1-6$

69. Palarea-Albaladejo J, Martín-Fernández JA. zCompositions - R package for multivariate imputation of left-censored data under a compositional approach. Chemom Intell Lab Syst. 2015 Apr;143:85-96.

70. Oksanen J, Blanchet GF, Friendly M, Kindt R, Legendre P, McGlinn D, et al.

578 71. Schwager E, Huttenhower C. banocc: Bayesian ANalysis Of Compositional Covariance. 2020.

72. Epskamp S, Cramer AOJ, Waldorp LJ, Schmittmann VD, Borsboom D. 
medRxiv preprint doi: https://doi.org/10.1101/2021.11.24.21266804; this version posted November 24,2021 . The copyright holder for this preprint (which was not certified by peer review) is the author/funder, who has granted medRxiv a license to display the preprint in

\section{$583 \quad$ Figure Legends}

584 Figure 1: A. Distribution of the top 10 most abundant bacterial genera in the vaginal microbiota of secretors and non-secretors in early, mid and late pregnancy. B. The

586 distribution of the proportion of Lactobacillus in secretors and non-secretors in early,

587 mid and late pregnancy was similar. C. Frequencies of each Community State Type

588 (CST) through pregnancy in secretors and non-secretors.

589 Figure 2: A. Co-occurrence networks showing the vaginal microbiata in early

590 pregnancy in secretors (left) and non-secretors (right). Nodes represent bacterial taxa

591 present in the $16 \mathrm{~S}$ relative abundance data (above our low abundance threshold of

$5920.5 \%$ in two or more samples), and have been grouped into $L$. crispatus, $L$. gasseri, $L$.

593 iners, L. jensenii, other Lactobacillus, BV-associated bacteria, Pathobionts, and Other,

594 as defined by previously ${ }^{33}$. Statistically significant edges, indicating correlations, are coloured and weighted according to their $r$ value: red and green, respectively indicate negatively and positively correlations. In both secretors and non-secretors, many of

597 the positive associations occur between BV-associated microbes, reflecting the

598 typically polymicrobial nature of BV. B. Flow diagrams (derived from the network analyses) centred on the L. crispatus, L. gasseri, L. iners and $L$. jensenii nodes indicate that these tend to be more negatively correlated with other bacteria in the vaginal

601 microbiota of the non-secretors compared with the secretors with L. crispatus having

602 the greatest proportion of negative edges, particularly in the non-secretors.

603 Figure 3: The association between secretor status, the vaginal microbiome and 604 gestational length (days). A red dashed line highlights the 37 weeks (259 days)

605 threshold for prematurity and sample sizes are indicated at the top of the plots. A. The 606 distribution of gestational length by secretor status and vaginal microbiome shows 607 non-secretors with Lactobacillus deplete microbiomes in early pregnancy tend to have 
medRxiv preprint doi: https://doi.org/10.1101/2021.11.24.21266804; this version posted November 24, 2021. The copyright holder for this preprint (which was not certified by peer review) is the author/funder, who has granted medRxiv a license to display the preprint in It is made available under a CC-BY-ND 4.0 International license.

608 shorter gestation but this relationship disappears by mid pregnancy. B. Classifying the

609 microbiome by Community State Type (CST) rather than by Lactobacillus status

610 indicates that reduced gestation in Lactobacillus deplete non-secretors is mainly

611 driven by women with CST 2 and high diversity CST 4 microbiomes. 
612 Table 1. Unstandardised coefficients (b), standard error (SE) and 95\% confidence intervals (CI) from gamma generalised 613 linear mixed effects modelling (GLMM) of gestational length (in days) over three time points in pregnancy (with ethnicity as 614 a random effect). Early, Mid and Late pregnancy GLMMs using Lactobacillus status (dominated/depleted), as well as an Early 615 Community State Type (CST) GLMM, which replaces the Lactobacillus covariate with CST. Secretors with Lactobacillus dominated 616 microbiota (or CST 1) are baseline in the model. ${ }^{* 1}$ Preterm birth. ${ }^{* 2}$ Mid-trimester loss. ${ }^{*} p<0.05 .{ }^{* *} p<0.01 .{ }^{* \star *} p<0.001$.

\begin{tabular}{|c|c|c|c|c|c|c|c|c|}
\hline Intercept & $\begin{array}{l}\text { Regression r } \\
\text { Early } \\
\text { b (SE) } \\
3.16(0.28)\end{array}$ & $\begin{array}{l}\mathrm{Cl} \\
2.62,3.71\end{array}$ & $\begin{array}{l}\text { Mid } \\
\text { b (SE) } \\
3.04(0.29)\end{array}$ & $\begin{array}{l}\mathrm{Cl} \\
2.48,3.60\end{array}$ & $\begin{array}{l}\text { Late } \\
\text { b (SE) } \\
2.91(0.29)\end{array}$ & $\begin{array}{l}\mathrm{Cl} \\
2.35,3.48\end{array}$ & $\begin{array}{l}\text { Early (CST) } \\
\text { b (SE) } \\
3.15(0.29)\end{array}$ & $\begin{array}{l}\mathrm{Cl} \\
2.58,3.72\end{array}$ \\
\hline Age & $0.002(0.01)$ & $-0.01,0.02$ & $0.01(0.01)$ & $-0.01,0.02$ & $0.01(0.08)$ & $-0.01,0.03$ & $0.01(0.01)$ & $-0.01,0.02$ \\
\hline $\mathrm{BMI}(<18.5)$ & $-0.12(0.41)$ & $-0.92,0.68$ & $-0.01(0.34)$ & $-0.68,0.67$ & $0.02(0.38)$ & $-0.72,0.75$ & $-0.1(0.41)$ & $-0.91,0.71$ \\
\hline $\begin{array}{l}\text { BMI (25.0- } \\
29.99)\end{array}$ & $0.09(0.09)$ & $-0.10,0.27$ & $0.01(0.1)$ & $-0.18,0.19$ & $0.09(0.1)$ & $-0.10,0.28$ & $0.1(0.1)$ & $-0.09,0.29$ \\
\hline $\mathrm{BMI}(>30.0)$ & $-0.16(0.13)$ & $-0.41,0.09$ & $-0.05(0.12)$ & $-0.28,0.18$ & $-0.13(0.12)$ & $-0.37,0.11$ & $-0.21(0.13)$ & $-0.47,0.05$ \\
\hline Cervical stitch & $0.33(0.09)^{* * *}$ & $0.16,0.50$ & $0.34(0.08)^{* * *}$ & $0.17,0.50$ & $0.21(0.08)^{*}$ & $0.04,0.37$ & $0.32(0.1)^{* * *}$ & $0.15,0.49$ \\
\hline $\begin{array}{l}\text { Previous } \\
\text { PTB }^{* 1} / \mathrm{MTL}^{* 2}\end{array}$ & $0.35(0.1)^{* * \star}$ & $0.16,0.54$ & $0.31(0.1)^{\star *}$ & $0.12,0.50$ & $0.23(0.1)^{*}$ & $0.04,0.43$ & $0.35(0.1)^{* * *}$ & $0.15,0.54$ \\
\hline $\begin{array}{l}\text { Previous } \\
\text { cervical } \\
\text { excisional } \\
\text { treatment }\end{array}$ & $-0.28(0.1)^{* *}$ & $-0.48,-0.08$ & $-0.28(0.1)^{* *}$ & $-0.47,-0.08$ & $-0.26(0.1)^{*}$ & $-0.45,-0.06$ & $-0.31(0.1)^{* *}$ & $-0.52,-0.11$ \\
\hline $\begin{array}{l}\text { Secretor } \times \\
\text { Lactobacillus }\end{array}$ & $0.53(0.23)^{*}$ & $0.07,0.99$ & $0.2(0.24)$ & $-0.27,0.67$ & $-0.16(0.23)$ & $-0.61,0.29$ & NA & NA \\
\hline $\begin{array}{l}\text { Secretor } \times \\
\text { CST } 2\end{array}$ & $\mathrm{NA}$ & NA & NA & NA & NA & NA & $0.84(0.34)^{*}$ & $0.17,1.51$ \\
\hline $\begin{array}{l}\text { Secretor } \times \\
\text { CST } 3\end{array}$ & NA & NA & NA & NA & NA & NA & $0.43(0.22)^{*}$ & $0.00,0.86$ \\
\hline
\end{tabular}


Secretor $x$

NA

NA

NA

NA

NA

NA

$0.85(0.35)^{\star}$

$0.17,1.52$

CST 4

Secretor $x$

NA

NA

NA

NA

NA

NA

$-0.11(0.43)$

$-0.95,0.73$ 
medRxiv preprint doi: https://doi.org/10.1101/2021.11.24.21266804; this version posted November 24, 2021. The copyright holder for this preprint (which was not certified by peer review) is the author/funder, who has granted medRxiv a license to display the preprint in perpetuity.

It is made available under a CC-BY-ND 4.0 International license .

A.

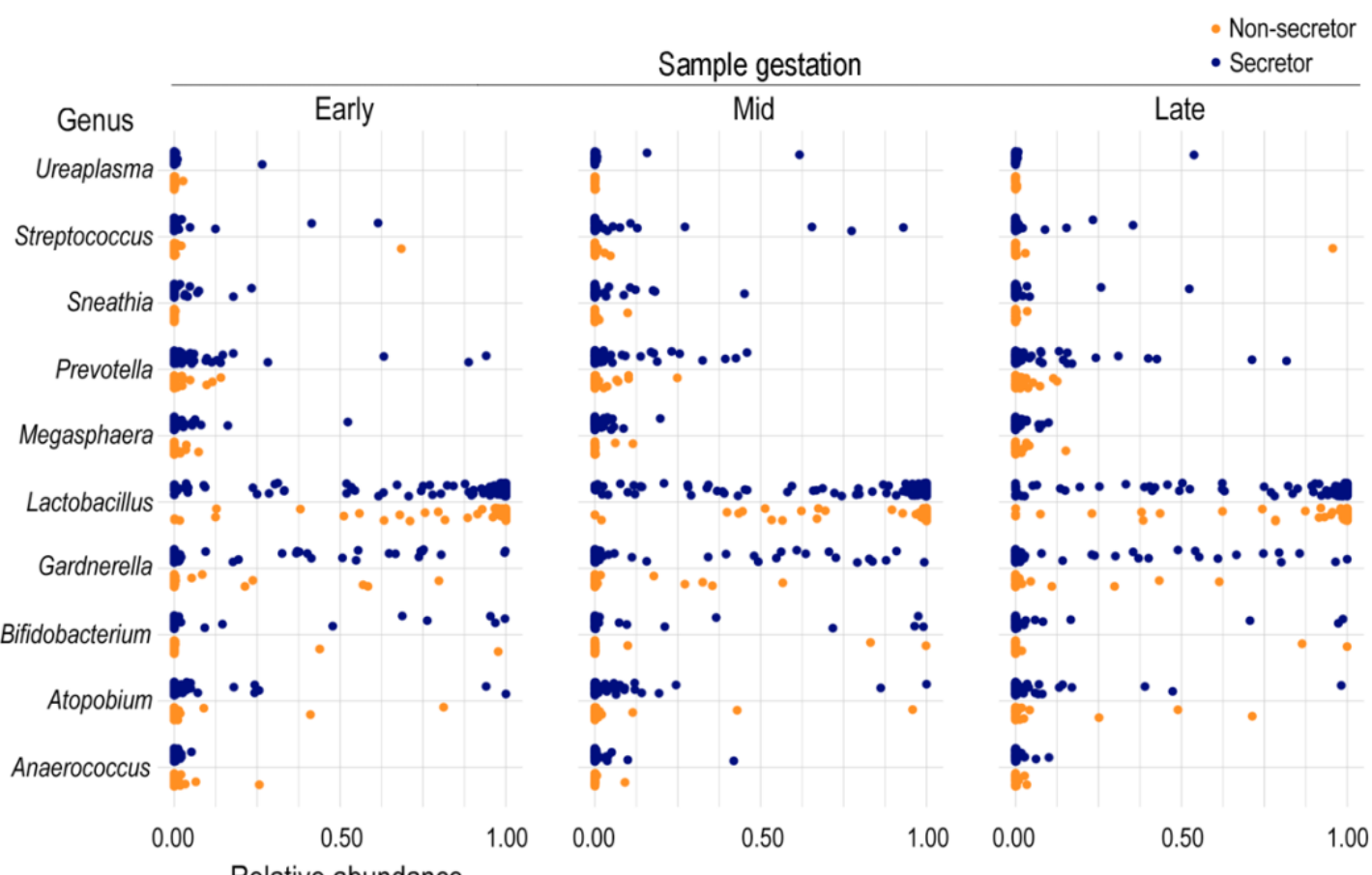

B.

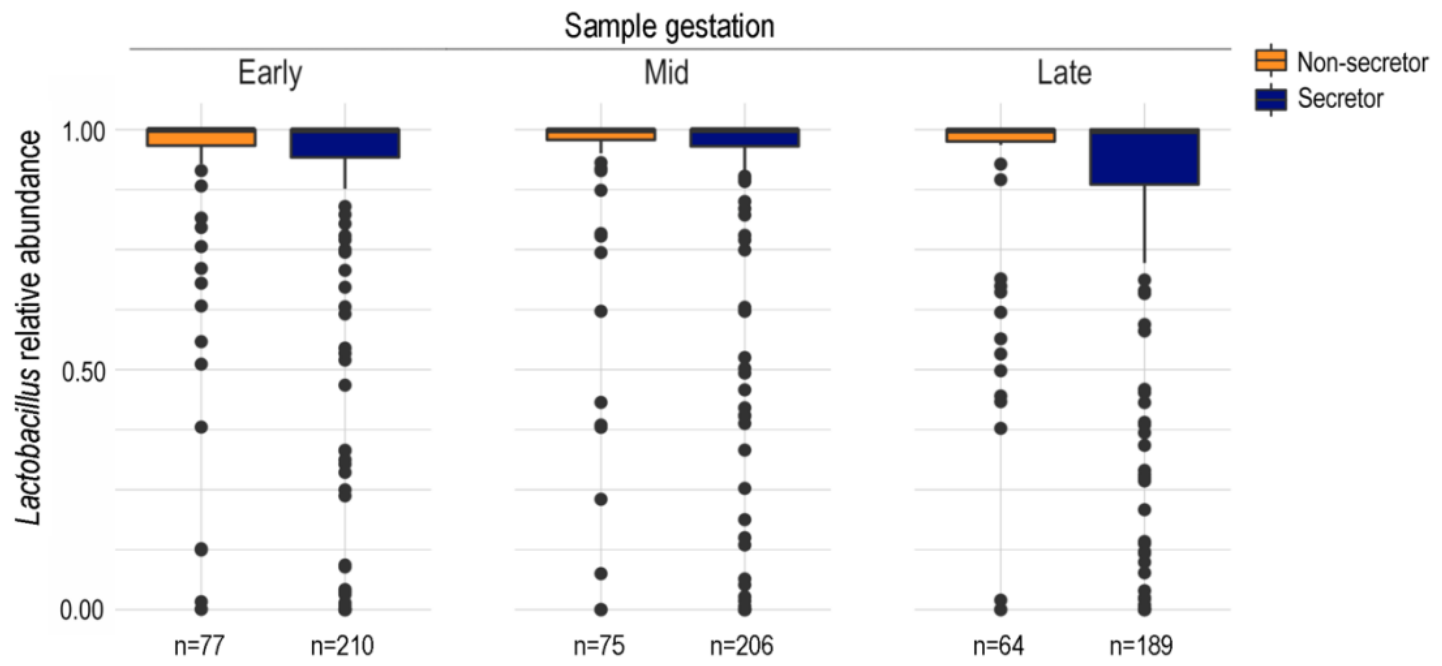

C.

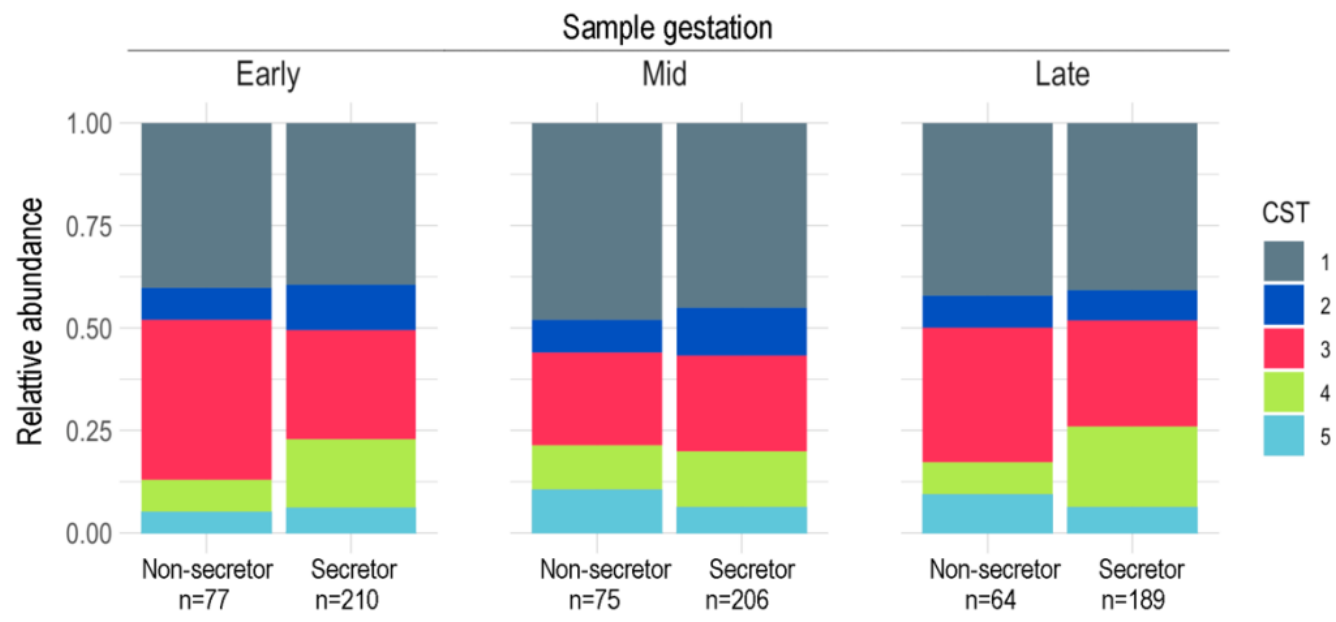

Figure 1 
medRxiv preprint doi: https://doi.org/10.1101/2021.11.24.21266804; this version posted November 24, 2021. The copyright holder for this preprint (which was not certified by peer review) is the author/funder, who has granted medRxiv a license to display the preprint in perpetuity.

It is made available under a CC-BY-ND 4.0 International license .

A.
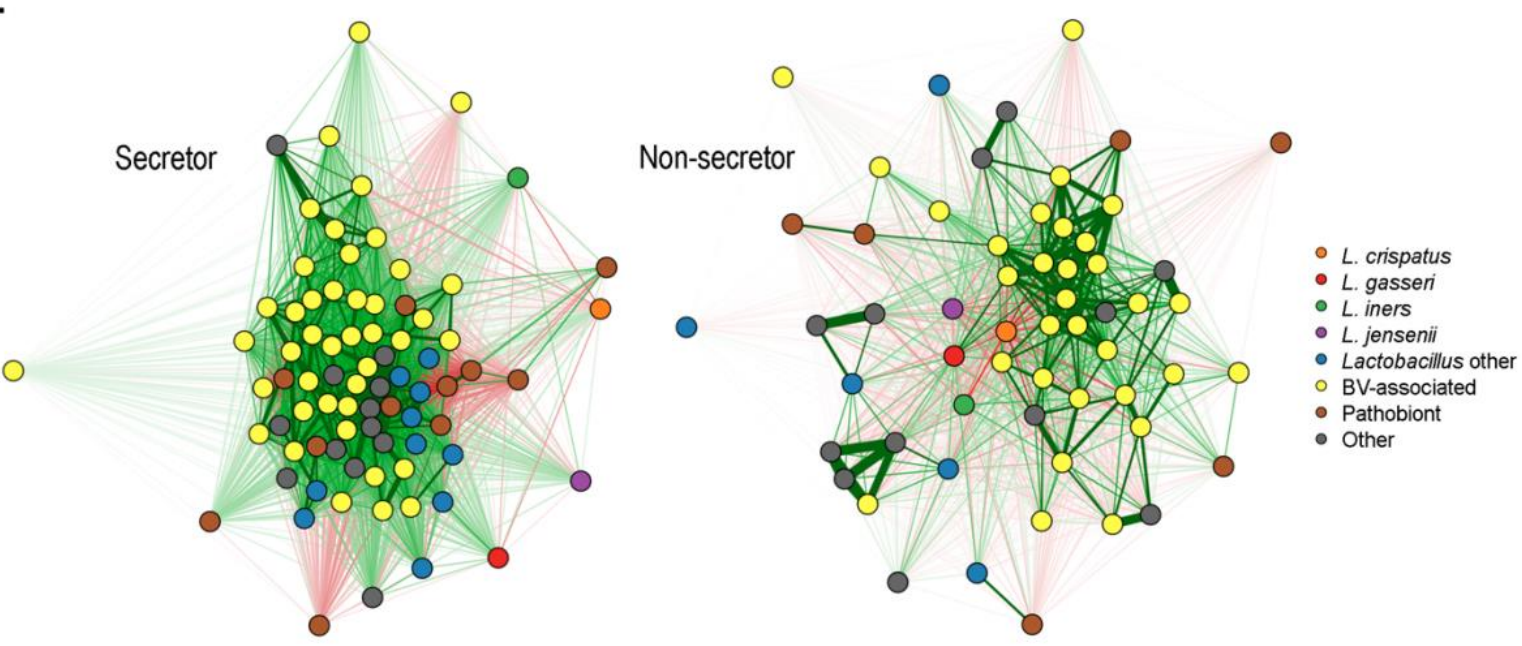

B.
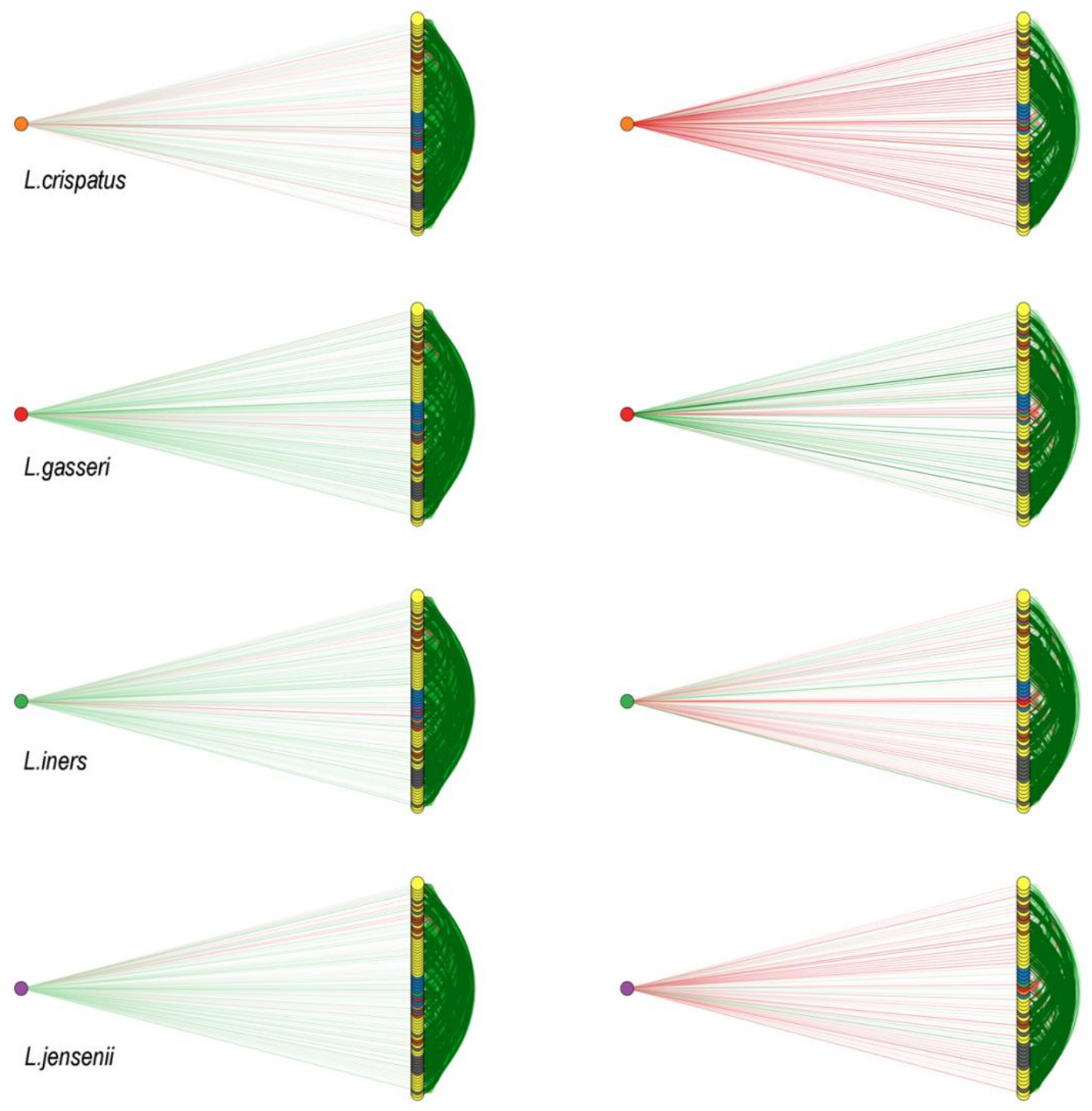

Secretor

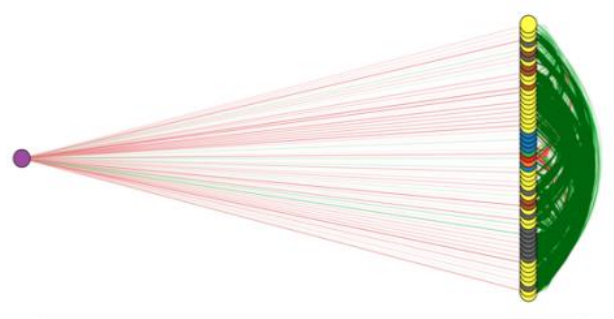

Non-secretor

Figure 2 
medRxiv preprint doi: https://doi.org/10.1101/2021.11.24.21266804; this version posted November 24, 2021. The copyright holder for this preprint (which was not certified by peer review) is the author/funder, who has granted medRxiv a license to display the preprint in perpetuity.

It is made available under a CC-BY-ND 4.0 International license.

A.

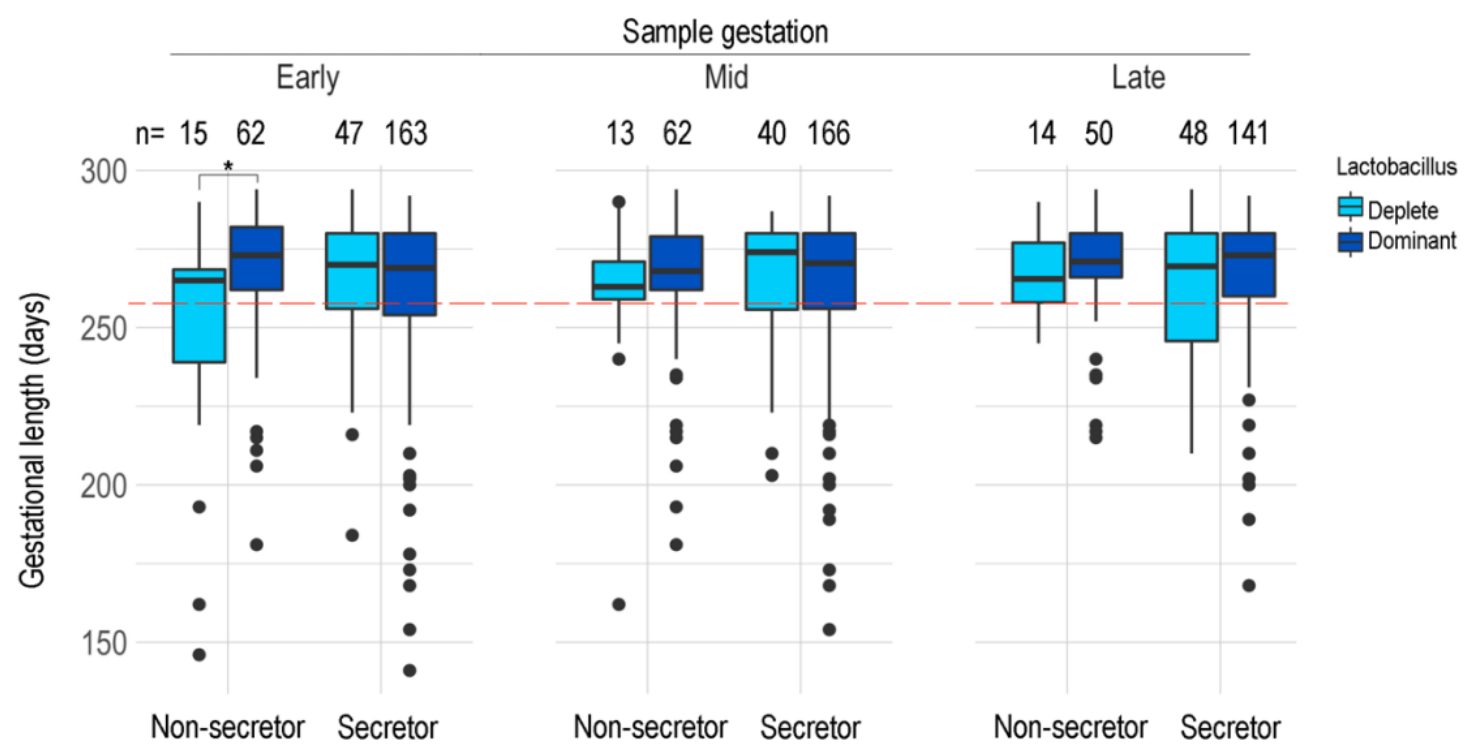

B.

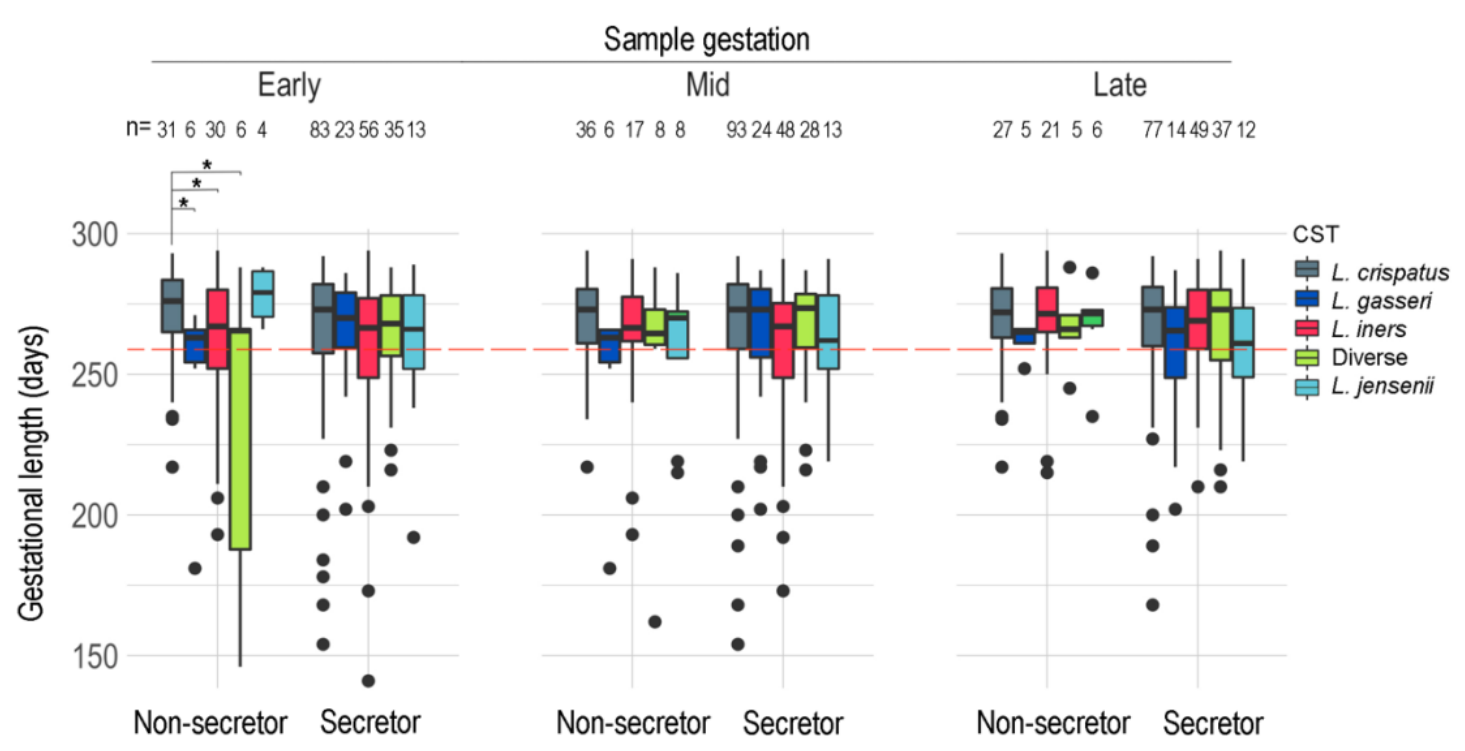

Figure 3 